\title{
Global output of research on the health of international migrant workers from 2000 to 2017
}

\author{
Waleed M. Sweileh
}

\begin{abstract}
Background: Approximately 150 million international migrant workers work under conditions that increase their risk of illness and injuries. The current study aimed to assess and analyze the global output of research on the health of international migrant workers to promote national and international policies that could help improve the health of international migrant workers.

Methods: A bibliometric methodology was implemented using Scopus database after retrieving documents relevant to the health of migrant workers during the study period from 2000 to 2017.

Results: In total, 955 documents were retrieved. The mean number of authors per document was 4.5 while the mean number of citation per document was 10.2. The retrieved documents were mainly in health policy and systems $(n=452 ; 47.3 \%)$, infectious diseases $(n=252 ; 26.4 \%)$, and mental and psychosocial health $(n=239 ; 25.0 \%)$. The health of Latino migrant farmworkers represented the largest cluster of keywords. The USA led $(n=389 ; 40.7 \%)$ with regard to the number of publications followed by China $(n=86 ; 9.0 \%)$ and the UK $(n=66 ; 6.9 \%)$. Researchers from the USA and Spain dominated the field. There were limited international research collaboration and a limited number and size of research networks. The American Journal of Industrial Medicine was most active (7.1\%; $n=68)$ in publishing documents on health of migrant workers while the Wake Forest University was the most active (10.9\%; $n=104)$ institution in this topic.

Conclusion: The volume of global research output on the health of migrant workers was low. There was inadequate research on non-communicable diseases and maternal health of migrant workers. International research collaboration and the number of research networks were limited. Role of several world regions, particularly Arab region with 11\% of international migrant workforce was also limited. There is an urgent need to prioritize research on migrant workers, especially female migrant workers in regions with low research contribution.
\end{abstract}

Keywords: Migrant workers, Health, Bibliometric analysis, Research activity

\section{Background}

In the past decade, there has been a significant increase in research about international migration due to its enormous economic, social, cultural, and health impact on both sending and receiving countries [1]. The term international migrant refers to any person who is moving or has moved across international borders $[2,3]$. The total number of international migrants has reached 258 million

Correspondence: waleedsweileh@yahoo.com

Department of Physiology, Pharmacology/Toxicology, Division of Biomedical

Sciences, College of Medicine and Health Sciences, An-Najah National

University, Nablus, Palestine

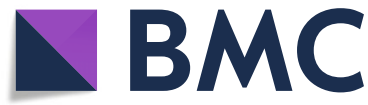

in $2017[4,5]$. Of this large number of international migrants 106 million were born in Asia, 61 million were born in Europe, 38 million were born in Latin America and the Caribbean, and 36 million were born in Africa. At the country level, India was the largest country of origin of international migrants (17 million), followed by Mexico (13 million). Other countries of origin with large migrant populations include the Russian Federation (11 million), China (10 million), Bangladesh (7 million), Syrian Arab Republic (7 million), and Pakistan and Ukraine (6 million each).

(C) The Author(s). 2018 Open Access This article is distributed under the terms of the Creative Commons Attribution 4.0 International License (http://creativecommons.org/licenses/by/4.0/), which permits unrestricted use, distribution, and reproduction in any medium, provided you give appropriate credit to the original author(s) and the source, provide a link to the Creative Commons license, and indicate if changes were made. The Creative Commons Public Domain Dedication waiver (http://creativecommons.org/publicdomain/zero/1.0/) applies to the data made available in this article, unless otherwise stated. 
International migrants comprise a wide range of populations, such as workers, refugees, students, undocumented migrants and others. Each type of migrants has different health needs and stressors. Health needs of this large number of people are important public health challenges faced by both sending and destination countries. Migration for work is the most common form of migration, particularly in a globalized world with profound economic and political disparities. Geographic proximity and historical links are also important motivating factors for the flow of migrant workers, particularly within the same region $[3,5]$.

The term migrant worker refers to all international migrants who are currently employed or are unemployed and seeking employment in their present country of residence [6]. According to the International Labour Organization [6], there are 150.3 million migrant workers in the world, with most living in high-income countries and many engaged in the service sector. Gender distribution showed that $55.7 \%$ of international migrant workers are males and $44.3 \%$ are females. Almost half of the migrant workers are concentrated in Northern America, Northern, Southern and Western Europe. The Arab region accounts for $11.7 \%$ of all migrant workers. Most international migrant workers are found in agricultural, construction, food processing, and other lowskilled jobs. It is estimated that 16.7 million international migrants were part of the agricultural labor workforce worldwide [6].

International migrant workers contribute positively to the economic situation of source countries through sending remittances $[7,8]$. Furthermore, migrant workers develop skills, learn new technologies, and make new social and professional connections that could benefit their home countries upon their return [9]. However, the health of migrant workers and the families they leave behind have not been given enough consideration by health-system planners in both sending and destination countries. Migrant workers are most vulnerable to health risks because they are often engaged in what is known as 3-D jobs-dirty, dangerous, and demanding (sometimes degrading or demeaning) [6]. For example, international migrant workers face several occupational hazards due to lack of training and/or appropriate safety measures [10]. Female migrant workers may be subjected to various types of violence and sexual exploitation $[11,12]$. Furthermore, migrant workers might face cultural and language barriers which could negatively affect the quality of healthcare services they receive [13-17]. A new dimension in the field of migrant workers health is the exploitation and abuse of labor and sex trafficked men, women and children, with negative health consequences on individuals and national health security [18-20]. In developed countries, such as the USA and UAE, there are employer agencies that recruit international workers from low- and middle-income countries (LMIC) by making fraudulent and false promises. Those migrant workers might end up being abused, slaved, mistreated, and deprived of basic medical and healthcare services. It is common for female migrant workers in some destination countries to end up as victims to sexual violence and harassment [21].

Despite the large numbers of migrant workers and the serious health threats they are facing, there has not been any assessment of the peer-reviewed literature on the health of migrant workers. Unfortunately, certain governments have the misconception that research about migrant workers could negate developmental gains or damage their political and human right reputation [22]. Furthermore, a recent study on the global migration health called for research assessment of migration health of all categories of international migrants to spot gaps for intervention and future policy implementation [23]. Therefore, the aim of this study was to assess and analyze the global output of research on the health of international migrant workers to spot research gaps, enrich the international research agendas pertaining to migration health, and create a research repository on this topic. Specifically, the study will examine the growth of publications, authorship analysis, geographical distribution, international research collaboration, important themes discussed, and highly cited articles. The overall aim of this study is to provide baseline data on health-related research issues on international migrant workers for future planning and comparison. Furthermore, this study is in agreement with the 2030 global agenda of health and human rights set in Sustainable Development Goals (SDGs) [24].

\section{Methods \\ Database}

A bibliometric methodology was implemented in this study. SciVerse Scopus was used to accomplish the objective of the current study since it was previously used in several bibliometric studies including those pertaining to migration health [25-33]. As a database, Scopus is larger than Web of Science and is $100 \%$ inclusive of Pubmed. Furthermore, Scopus has several functions that facilitate research trends, citation analysis, mapping of keywords, and international research collaboration.

\section{Study duration and language}

The duration of the study was set from January 2000 until December 2017. This was judged to capture most studies on the health of migrant workers. Scopus allows researchers to filter the retrieved documents based on the language of the documents. Yet, in this study, no language restriction was made and all retrieved documents, regardless of their language, were analyzed. Documents appearing in Scopus must have an English 
abstract, and therefore, the relevancy of any retrieved document could be confirmed by reading the English abstract regardless of the original language of the document.

\section{Search strategy}

The search strategy utilized several different keywords in title search. Examples of keywords used include ""migrant "worker" or "*migrant laborer" or "migrant labourer" or ("*migrant" and "worker") or ("migrant and laborer") or ("migratory worker"). The author was careful to use all potential keywords related to migrant workers. Therefore, a survey of literature on migrant workers was carried out before deciding on keywords [34-40]. Furthermore, the keywords used in the current study were partially extracted from the bibliometric study by Sweielh et al. on global migration health in which migrant workers' health was one component [23]. The health component of the search strategy was defined as documents classified by Scopus to be within the following subject areas: medicine, psychology, nursing, biochemistry, immunology, pharmacology, toxicology, dentistry, and neuroscience. These subject areas are available through Scopus and can selected to refine the retrieved documents to health component.

\section{Exclusion criteria}

The current study focused on international migrant workers and therefore documents about internal migrants or documents pertaining to urban-to-rural or rural-to-urban documents were excluded. Furthermore, documents pertaining to health professionals such as nurses or physicians (brain drain) were also excluded because this category is usually well-paid and has better working conditions than the bulk of international migrant workers.

\section{Validity check}

The validity of the search strategy was explained in previously published studies [23, 41]. The validity check consisted of two approaches, one to confirm the absence of false positive results and one to confirm the absence of false negative results. To confirm absence of false positive results a sample of top 100 cited documents were reviewed. For the absence of false negative results, the number of documents for each of the top ten active authors was compared with the number present in the personal profile of each of the top ten active authors. A correlation coefficient greater than 0.95 is indicative of the absence of false positive results.

Once the retrieved documents were refined and all false positive documents were excluded, a set of analytic functions were implemented to produce the required bibliometric indicators.

\section{Research domains}

For the classification of research domains of the retrieved documents, five domains were created: health policy and systems, mental and psychosocial health, maternal and reproductive health, non-communicable diseases, and infectious diseases. These domains fall within the large domain of public health. However, this classification better serves the analysis for finding research gaps. The health policy and systems domain included documents in health system, health services, access to healthcare, human rights, rights to health, hospitalization, medical services, emergency room visits, occupational health, and migration policies [1]. Occupational health documents were categorized under the domain "health policy and systems" because it is a consequence of job regulations and availability of health insurance and health services.

\section{Bibliometric analysis and indicators}

Retrieved data were exported into Microsoft Excel for calculation and tabulation. Scopus has several functions that can generate bibliometric indicators. Such functions include annual growth, citations, source title, country list, author list, institution list, and types of documents. For data visualization, the retrieved documents were visualized using VOSviewer (version 1.6.8; Leiden University, the Netherlands) to create three types of maps: keyword occurrences, international research collaboration, and author research network [42]. ArcMap 10.1 (Esri, California, USA) is a GIS program that was used to map the distribution of retrieved documents based on author affiliation.

All through the manuscript, frequency and percentages were provided in tables. For line of best fit and best line equation, Statistical Package for Social Sciences (IBM SPSS statistics; version 21; Armonk, N.Y: IBM Corporation) program was used. For the impact of the retrieved documents, Hirsh index ( $h$-index) was used [43]. The rank of each journal in the top active list was obtained from Scimago Journal Rank website [44]. The impact factor (IF) of the most active publishing journal was obtained from the most recent Journal Citation Report.

\section{Research ethics}

Finally, the current study was based on electronic data and no human subjects were directly involved and therefore the ANU-IRB office did not require an approval of the study.

\section{Results}

Types of documents

Nine hundred and fifty-five documents were retrieved based on the methodology described. Research articles $(85.5 \% ; n=817)$ constituted the majority of retrieved 
documents followed by review articles $(6.0 \% ; n=57)$, and letters to the editor $(2.5 \% ; n=24)$ (Table 1$)$.

\section{Citation analysis and top cited documents}

The retrieved documents received 9725 citations, an average of 10.2 citations per documents. The $h$-index of the retrieved documents was 42 . The top 10 cited documents were either in the mental and psychosocial health [45-48] or in the health policies and systems, specifically in occupational health [49-53] (Table 2). The document that received the highest citations (150 citations) was published in the American Journal of Public Health [48]. The document discussed the prevalence of psychiatric disorders among Mexican migrant farmworkers in California. The top 10 documents included one document in infectious diseases [54].

\section{Research domains}

Analysis of the retrieved literature revealed that 239 (25.0\%) documents were on mental and psychosocial health of migrant workers; $452(47.3 \%)$ documents on health policy and systems (including occupational health), $24(2.5 \%)$ documents on non-communicable diseases (NCD); 252 (26.4\%) on infectious diseases; 111 (11.6\%) on maternal and reproductive health (Table 3). There is an overlap among various research domains, which made the total percentage to be more than $100 \%$.

\section{Most frequent author keywords}

Mapping keywords with minimum occurrences of 10 yielded a map with 17 items distributed in four clusters (Fig. 1). The largest cluster focused on the occupational health of Latino migrant farmworkers. The blue and green clusters focused on the mental and psychosocial health of Latino/Hispanic migrant workers. The fourth cluster focused on the epidemiology of HIV in China in relation to migrant workers.

Table 1 Types of retrieved documents on health of migrant workers (2000-2017)

\begin{tabular}{lll}
\hline Type of document & $\begin{array}{l}\text { Number of documents } \\
N=955\end{array}$ & $\%$ \\
\hline Article & 817 & 85.5 \\
Review & 57 & 6.0 \\
Letter & 24 & 2.5 \\
Note & 21 & 2.2 \\
Conference Paper & 13 & 1.4 \\
Editorial & 10 & 1.0 \\
Short Survey & 6 & 0.7 \\
Article in Press (unidentified type) & 7 & 0.6 \\
\hline
\end{tabular}

\section{Growth of publications}

The number of publications showed slow increments over time. Plotting the number of publications versus time yielded a straight line with $\mathrm{R}^{2}=0.95$ (Fig. 2). According to the equation of the straight line $(Y=5.4 \mathrm{X}-10,800)$, it is expected that the number of publications in 2020 and 2030 on migrant workers' health to be approximately 108 and 162 respectively; i.e. an increase by $50 \%$ during a decade interval (2020 to 2030).

\section{Top 10 active countries}

Authors from 77 different countries participated in publishing the retrieved documents. The contribution of US researchers was the highest $(389 ; 40.7 \%)$ followed by those from China $(86 ; 9.0 \%)$ and the UK $(66 ; 6.9 \%)$. The list of top 10 active countries (Table 4) included three countries in South Eastern Pacific region, two countries in South East Asia, three countries in Western Europe, and two countries in Northern America. None of the active countries was from South America or Eastern Mediterranean, or Eastern Europe, or Africa. Geographic distribution of publications based on the country affiliation of all authors showed the prominent contribution of the US, Canada, Australia, certain European countries, and certain countries in South-Eastern Asia (Fig. 3).

\section{International research collaboration}

The top 10 active countries showed limited research collaboration as visualized by the thickness of the connecting lines between the countries. Relatively speaking, research collaboration in migrant workers' health research was the strongest between the USA and China (Fig. 4).

\section{Top 10 active authors and research networks}

In total, 4300 authors participated in publishing the retrieved documents, an average of 4.5 authors per article. Approximately $15 \%(n=140)$ documents were single-authored publications while the remaining were multiple-authored publications. The top 10 active authors were listed in Table 5. Professors Arcury, T.A and Quandt, S.A (Wake Forest University School of Medicine, U.S) had a prominent role in health research of migrant workers. The top 10 active authors were mainly from the USA and Spain. Mapping active authors showed that they existed in two research networks (Fig. 5). The largest research network included eight authors; all were from the USA. The smaller research network included four researchers, mainly from Spain. Researchers in the large network were mainly from the same institution (Wake Forest University). Due to research collaboration within each research network, there is a lot of overlap in the number of publications produced by each researcher. 
Table 2 Top 10 cited documents on health of migrant workers (2000-2017)

\begin{tabular}{|c|c|c|c|c|}
\hline$\overline{S C R^{a}}$ & Title & Year & Source & Number of citations \\
\hline $1 s t$ & $\begin{array}{l}\text { Lifetime prevelance of and risk factors for psychiatric } \\
\text { disorders among Mexican migrant farmworkers in California }\end{array}$ & 2000 & American Journal of Public Health & 150 \\
\hline 2nd & $\begin{array}{l}\text { Psychosocial stressors associated with Mexican migrant } \\
\text { farmworkers in the midwest United States. }\end{array}$ & 2003 & Journal of immigrant health & 121 \\
\hline $3 \mathrm{rd}$ & $\begin{array}{l}\text { Immigrant populations, work and health - A systematic } \\
\text { literature review }\end{array}$ & 2007 & $\begin{array}{l}\text { Scandinavian Journal of Work, Environment } \\
\text { and Health }\end{array}$ & 116 \\
\hline 4th & $\begin{array}{l}\text { Work characteristics and pesticide exposures among } \\
\text { migrant agricultural families: A community-based } \\
\text { research approach }\end{array}$ & 2001 & Environmental Health Perspectives & 108 \\
\hline 4th & $\begin{array}{l}\text { Agricultural injury in California migrant Hispanic } \\
\text { farm workers }\end{array}$ & 2003 & American Journal of Industrial Medicine & 108 \\
\hline 6th & $\begin{array}{l}\text { Occupational risks and injuries in non-agricultural } \\
\text { immigrant Latino workers }\end{array}$ & 2002 & American Journal of Industrial Medicine & 103 \\
\hline 7th & $\begin{array}{l}\text { Use of commercial sex workers among Hispanic migrants } \\
\text { in North Carolina: Implications for the spread of HIV }\end{array}$ & 2004 & Perspectives on Sexual and Reproductive Health & 101 \\
\hline 8th & $\begin{array}{l}\text { Psychosocial predictors of anxiety among immigrant Mexican } \\
\text { migrant farmworkers: Implications for prevention and treatment }\end{array}$ & 2002 & Cultural Diversity and Ethnic Minority Psychology & 91 \\
\hline 9th & $\begin{array}{l}\text { Leaving family for work: Ambivalence and mental health } \\
\text { among Mexican migrant farmworker men }\end{array}$ & 2006 & Journal of Immigrant and Minority Health & 89 \\
\hline 10th & $\begin{array}{l}\text { Farmworker reports of pesticide safety and sanitation in } \\
\text { the work environment }\end{array}$ & 2001 & American Journal of Industrial Medicine & 76 \\
\hline
\end{tabular}

SCR Standard competition ranking;

${ }^{a}$ Equal citations have the same ranking number, and then a gap is left in the ranking numbers

\section{Preferred journals for publishing documents on migrant workers' health}

The American Journal of Industrial Medicine was the most active $(7.1 \% ; n=68)$. The list of active journals included seven journals in in public health, two in general medicine, and one in general science (Table 6). Half the active journals were published from the USA, four from Europe, and one from China. Four journals in the active list were categorized as high rank (Q1) journals. Eight journals in the active list were indexed in ISI-Web of Science and had an impact factor [55] according to Journal Citation Report (JCR; 2017). All journals in the active list were indexed in Scopus.

\section{Top 10 active institutions}

The top 10 active institutions were led by Wake Forest University $(10.9 \% ; n=104)$ followed by two universities

Table 3 Research domains of the retrieved documents (2000-2017)

\begin{tabular}{ll}
\hline Research domain & $\begin{array}{l}\text { Number of publications (\%) } \\
N=955\end{array}$ \\
\hline Mental and psychosocial health & $239(25.0 \%)$ \\
Health policy and systems ${ }^{a}$ & $452(47.3 \%)$ \\
Non-communicable diseases (NCD) & $24(2.5 \%)$ \\
Infectious diseases & $252(26.4 \%)$ \\
Maternal and reproductive health & $111(11.6 \%)$ \\
\hline
\end{tabular}

${ }^{\mathrm{a}}$ This domain includes occupational health-related documents in Spain (Table 7). The active list included six institutions in the USA (four academic and two non-academic institutions). The list also included three academic institutions in Spain, one in Thailand, one in China, and one in Colombia. Two of the active institution (Wake Forest University and The University of North Carolina at Greensboro) were based in North Carolina (USA).

\section{Discussion}

The current study aimed to analyze and assess published literature on the health of migrant workers. Such analysis helps in addressing and optimizing clear strategies in both sending and destination countries to protect migrant workers. The current study showed that the volume of the retrieved literature was relatively low. A bibliometric analysis of literature on global migration health conducted by Sweileh et al. showed that a volume of more than 20,000 documents was published on global migration health from 2000 to 2016 [23]. This means that literature on the health of migrant workers represents less than $5 \%$ of the overall literature. The relatively lower volume of literature on health of migrant workers could be due to the limited number of worldwide scholars interested in the health of migrant workers. Furthermore, the health issues of migrant workers are usually hidden ones and might be difficult to research given the idea that migrant workers tend not to talk about their negative experiences to avoid losing their jobs [56]. A third potential reason is the fact that serious 


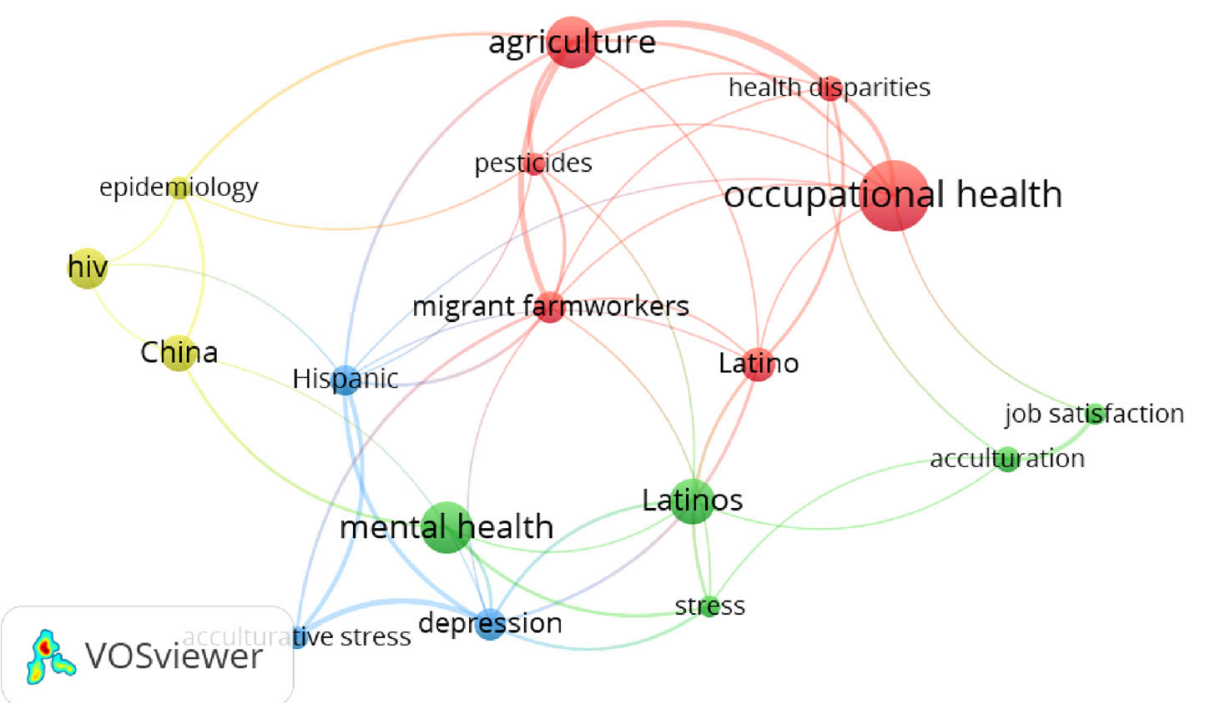

Fig. 1 Visualization map of keywords with minimum occurrence of 10

health issues of massive numbers of refugees dominated the field of migration health [1].

Analysis of research domains of the retrieved literature showed that research about occupational health dominated the field. However, the number of publications could be much higher if research about migrant workers was not complicated by issues related to employees and hidden working conditions [56]. Migrant workers often serve in jobs that natives are reluctant to perform [57]. Thus, migrants are more often exposed to potentially health-damaging work environments than native workers [58]. A review study on the occupational health of migrant workers in the USA showed that the proportion of fatal and nonfatal workplace injuries has been increasing among migrant workers due to the shift in hazardous jobs to the immigrant workforce [59].

Publications in communicable diseases among migrant workers were also evident in the retrieved literature. One concern of health officials in destination countries is that the sending countries tend to have higher prevalence of infectious diseases and less screening systems, which increases the risk of disease importation [60]. The focus on infectious diseases among migrant workers is also based on the idea that migrant workers might have

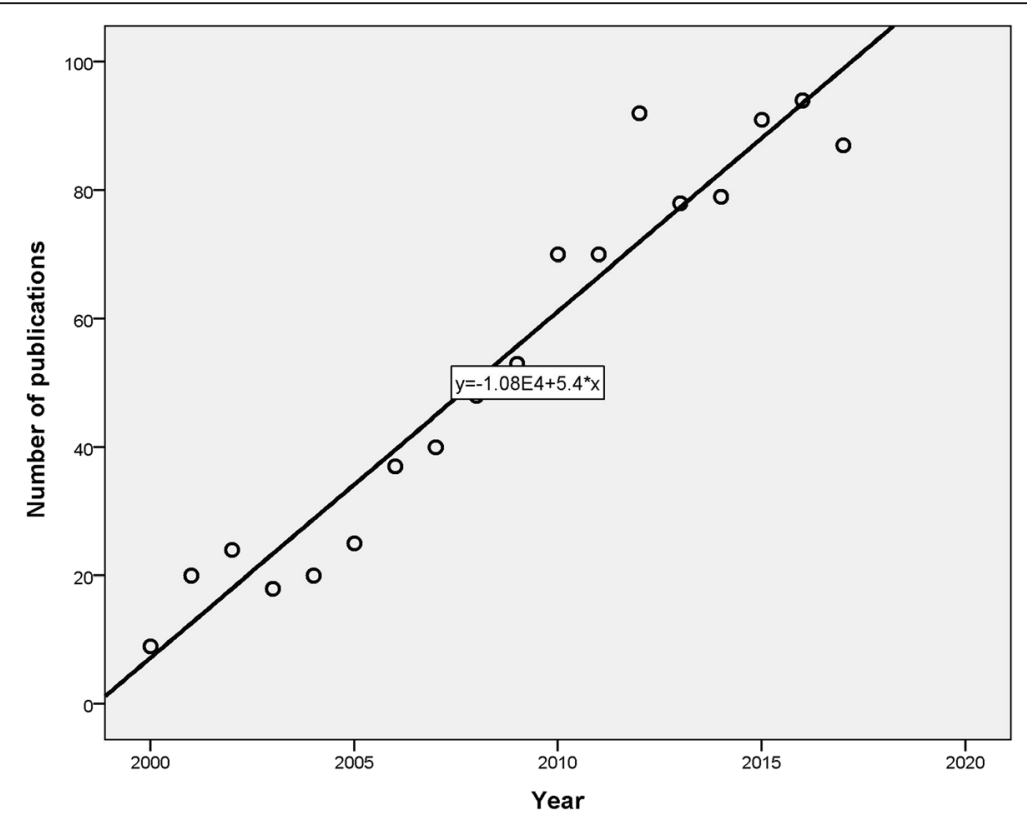

Fig. 2 Lines of best fit for annual growth of publications 
Table 4 Top 10 active countries on migrant workers' health research (1988-2017)

\begin{tabular}{lll}
\hline SCR & Country & $\begin{array}{l}\text { Number of publications (\%); } \\
N=955\end{array}$ \\
\hline 1st & United States & $389(40.7)$ \\
2nd & China & $86(9.0)$ \\
3rd & United Kingdom & $66(6.9)$ \\
4 th & Canada & $48(5.0)$ \\
5 th & Thailand & $46(4.8)$ \\
6 th & Spain & $40(4.2)$ \\
7 th & Australia & $34(3.6)$ \\
8th & Italy & $33(3.5)$ \\
9 th & Malaysia & $24(2.5)$ \\
10th & India & $23(2.4)$
\end{tabular}

SCR Standard competition ranking

higher risk of infections than non-migrants probably due to risky sexual behaviors, socio-economic factors, their living conditions and financial, language and cultural barriers to healthcare access [61-63]. Both sending and destination countries need to have an improved screening and preventive measures to limit potential spread of certain serious infections carried by travelers [64]. For example, the rapid spread of pandemic (H1N1) influenza in Mexico led to fears among health officials in North America of potential transmission of the diseases by
Mexican migrant workers. To avoid negative opinion and to contain the spread of the infection, health officials in Mexico and North America immediately implemented screening of migrant workers both at departure and arrival points.

The retrieved literature also included relatively good volume of publications on mental health of migrant workers and their families. The cultural shock and acculturative stress in addition to barriers to access healthcare services increase the risk of depression, stress and risk of suicide among migrant workers [65-68]. Furthermore, work environment that might include physical abuse and harassment is a potential cause for negative mental health outcomes [37]. The presence of several documents about occupational health in the top ten cited documents emphasized the good share of research on occupational health in the retrieved documents.

The current study showed relatively lower research activity on NCDs on migrant workers. One potential reason for that is the fact that migrant workers are usually young and might not have a high prevalence of NCD compared to elderly people. However, migrant workers might get engaged in risky life style such as chronic tobacco smoking or alcohol abuse that could lead to NCD [69]. Furthermore, those with existing chronic illness might experience deterioration of their chronic disease due to interrupted healthcare services or lack of access

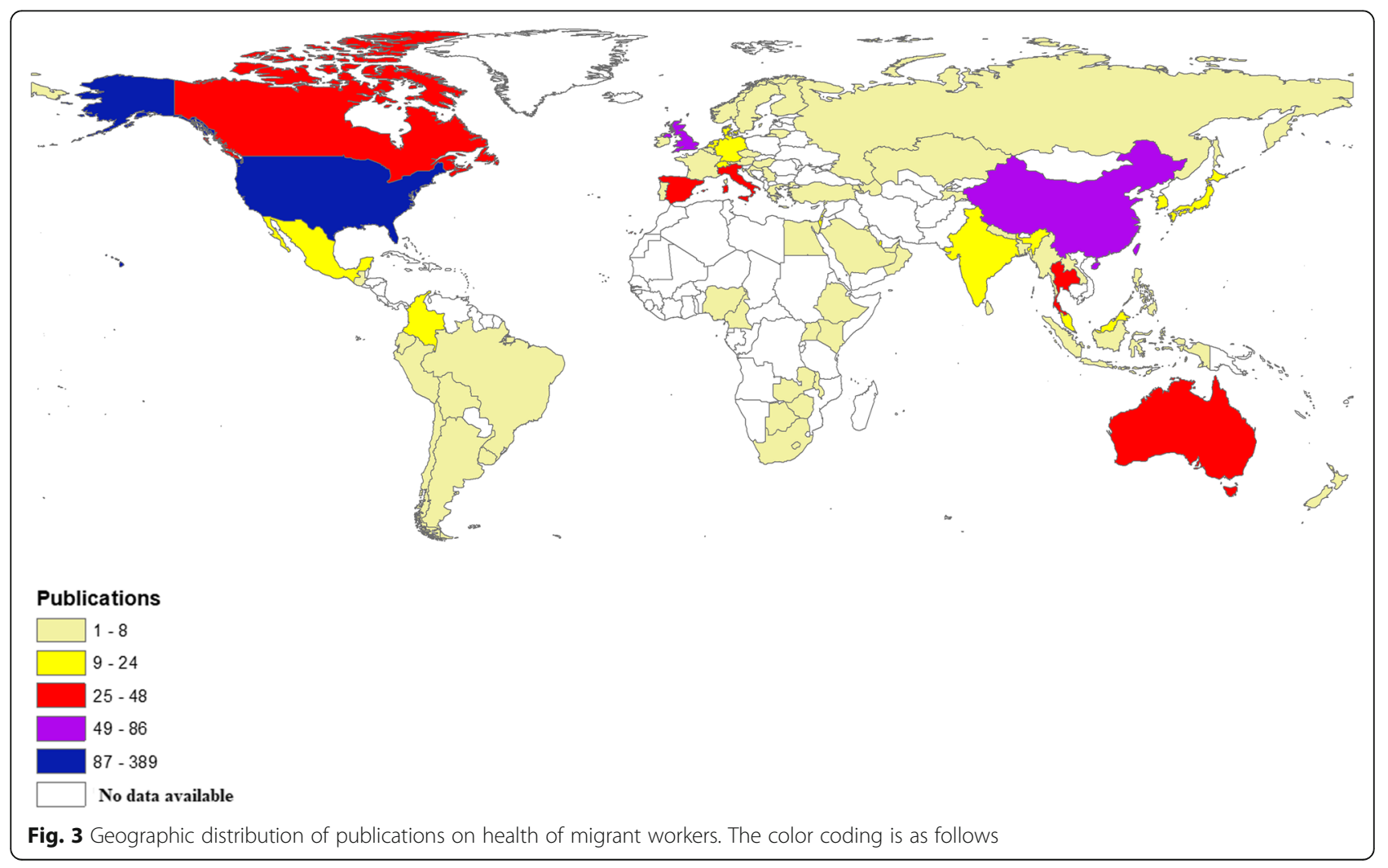




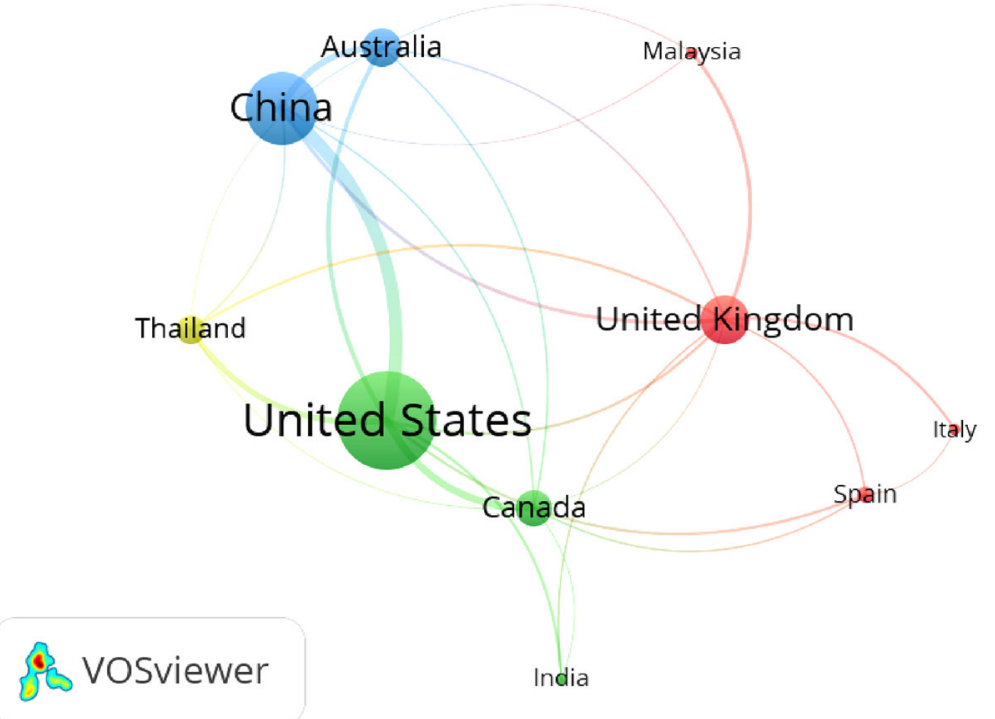

Fig. 4 International research collaboration among top 10 active countries. Thickness of the connecting line represents strength of research collaboration. Similar color represents research relatedness

to medications and medical follow up [70-72]. Another important factor when considering NCD among migrant workers is affordability to cover for medications when needed which ultimately affects the health of migrant workers [55]. Maternal and reproductive health research domain was also dwarfed on the expense of occupational health and mental health domains. Female migrant workers often face more barriers related to reproductive healthcare, access to health services, child care, family planning services, prenatal care, and unplanned pregnancies than do native-born women [73, 74].

The current study showed that countries, researchers, and institutions in high-income destination countries contributed to a large percentage of retrieved documents. In

Table 5 Top 10 active countries on migrant workers' health research (1988-2017)

\begin{tabular}{|c|c|c|c|}
\hline$\overline{S C R^{a}}$ & Author & Number of publications (\%); $N=955$ & Affiliation as it appeared in Scopus profile \\
\hline 1st & Arcury, T.A. & $101(10.6)$ & $\begin{array}{l}\text { Wake Forest University School of Medicine, Department of Family \& } \\
\text { Community Medicine, Winston Salem, U.S }\end{array}$ \\
\hline 2nd & Quandt, S.A. & $96(10.1)$ & $\begin{array}{l}\text { Wake Forest University School of Medicine, Center for Worker Health, } \\
\text { Winston Salem, U.S }\end{array}$ \\
\hline $3 \mathrm{rd}$ & Chen, $\mathrm{H}$. & $46(4.8)$ & $\begin{array}{l}\text { Wake Forest University School of Medicine, Center for Worker Health, } \\
\text { Winston Salem, U.S }\end{array}$ \\
\hline 4th & Grzywacz, J.G. & $40(4.2)$ & $\begin{array}{l}\text { Florida State University, Department of Family and Child Sciences, } \\
\text { Tallahassee, U.S }\end{array}$ \\
\hline 5th & Benavides, F.G. & $21(2.2)$ & $\begin{array}{l}\text { Universitat Pompeu Fabra, Centro de Investigación en Salud Laboral, } \\
\text { Barcelona, Spain }\end{array}$ \\
\hline 6th & Summers, $\mathrm{P}$. & $19(2.0)$ & $\begin{array}{l}\text { Wake Forest University School of Medicine, Clinical and Translational } \\
\text { Science Institute, Winston Salem, U.S }\end{array}$ \\
\hline 7th & Mora, D.C. & $18(1.9)$ & $\begin{array}{l}\text { Wake Forest University School of Medicine, Department of Family \& } \\
\text { Community Medicine, Winston Salem, U.S }\end{array}$ \\
\hline 8th & Vallejos, Q.M. & $17(1.8)$ & $\begin{array}{l}\text { The University of North Carolina at Greensboro, Department of Public } \\
\text { Health Education, Greensboro, U.S }\end{array}$ \\
\hline 9th & Ronda-Pérez, E. & $16(1.7)$ & Universitat d'Alacant, Public Health Research Group, Alicante, Spain \\
\hline 10th & Agudelo-Suárez, A.A. & $15(1.6)$ & Universidad de Antioquia, Faculty of Dentistry, Medellin, Colombia \\
\hline 10th & García, A.M. & $15(1.6)$ & Universitat de Valencia, Valencia, Spain \\
\hline 10th & Feldman, S.R & $15(1.6)$ & Wake Forest University School of Medicine, Winston \\
\hline
\end{tabular}

SCR Standard competition ranking;

${ }^{a}$ Equal authors have the same ranking number, and then a gap is left in the ranking numbers 


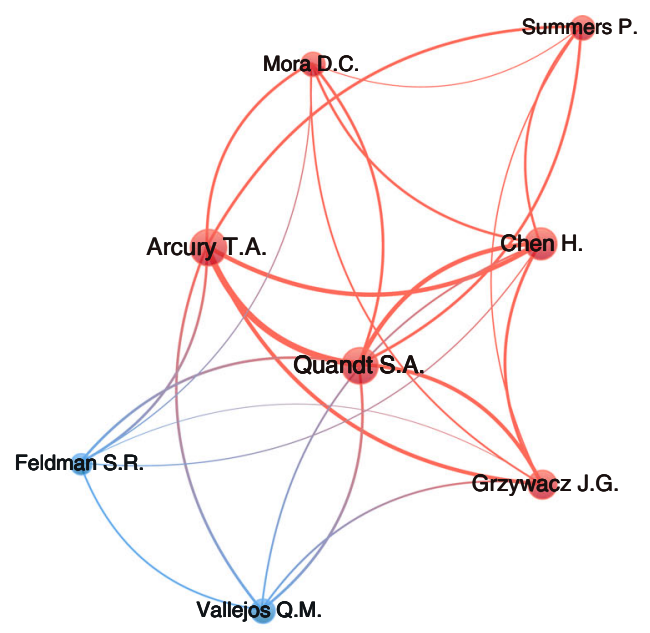

VOSviewer

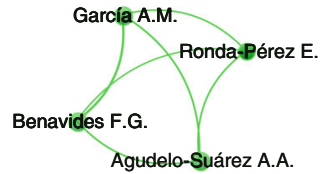

Fig. 5 Research networks among top 10 active authors

destination countries, migration has important public health consequences that can affect the national healthcare system. Research experts and research budgets in destination countries are key reasons for the prominent research role of these countries. The findings in the current study showed that China is one of the top ten active countries in research about health of migrant workers. China has become not only a source, but also a destination for migrants from all over the world. There are 60 million overseas Chinese around the world according to the Annual Report on Chinese International Migration [75]. Other Asian countries such as Malaysia, India,

Table 6 Top 10 active journals in publishing documents on migrant workers' health (2000-2017)

\begin{tabular}{|c|c|c|c|c|c|c|}
\hline$S C R^{a}$ & Journal (Country) & $\begin{array}{l}\text { Number of publications } \\
(\%) ; N=955\end{array}$ & Subject area (category) & $\operatorname{Rank}^{\mathrm{b}}$ & Country & $\mathrm{IF}^{c}$ \\
\hline 1 st & American Journal Of Industrial Medicine & $68(7.1)$ & Medicine (Pubic health) & Q1 & USA & 1.729 \\
\hline 2nd & Journal Of Immigrant And Minority Health & $50(5.2)$ & Medicine (Epidemiology/Pubic health) & Q3/Q2 & Germany & 1.284 \\
\hline $3 r d$ & Journal Of Agromedicine & $29(3.0)$ & Medicine (Pubic health) & Q2 & USA & 1.322 \\
\hline 4th & BMC Public Health & $20(2.1)$ & Medicine (Pubic health) & Q1 & UK & 2.265 \\
\hline 5 th & $\begin{array}{l}\text { Journal Of Occupational And Environmental } \\
\text { Medicine }\end{array}$ & $15(1.6)$ & Medicine (Pubic health) & Q2 & USA & 1.355 \\
\hline 5th & Plos One & $15(1.6)$ & $\begin{array}{l}\text { Agricultural and Biological Sciences } \\
\text { (Miscellaneous) }\end{array}$ & Q1 & USA & 3.54 \\
\hline 7th & $\begin{array}{l}\text { Chinese Journal Of Industrial Hygiene And } \\
\text { Occupational Diseases }\end{array}$ & $13(1.4)$ & Medicine (Miscellaneous) & Q4 & China & NA \\
\hline 8th & AIDS And Behavior & $12(1.3)$ & $\begin{array}{l}\text { Medicine (Infectious disease/Public } \\
\text { Health/ Social Psychology) }\end{array}$ & Q1/Q1 & Netherlands & 3.017 \\
\hline 8th & $\begin{array}{l}\text { New Solutions A Journal Of Environmental } \\
\text { And Occupational Health Policy Ns }\end{array}$ & $12(1.3)$ & Medicine (Miscellaneous) & Q3 & USA & NA \\
\hline 10th & $\begin{array}{l}\text { International Journal Of International Journal } \\
\text { of Environmental Research And Public Health }\end{array}$ & $11(1.2)$ & Medicine (Toxicology/Public Health) & Q2/Q2 & Switzerland & 2.145 \\
\hline
\end{tabular}

SCR Standard competition ranking, IF Impact Factor, NA Not available

${ }^{a}$ Equal journals have the same ranking number, and then a gap is left in the ranking numbers

bJournal rank was obtained from Scimago Journal rank. Q1 = highest rank; Q4 = lowes rank

'The impact factor was reported according to journal citation reports (JCR) 2017 
Table 7 Top 10 active institutions in migrant workers' health research (2000-2017)

\begin{tabular}{llll}
\hline SCR $^{a}$ & Institution & Number of publications (\%); N=955 & Country \\
\hline 1 st & Wake Forest University & $104(10.9)$ & USA \\
2nd & Universitat d'Alacant & $22(2.3)$ & Spain \\
3rd & Universitat Pompeu Fabra & $21(2.2)$ & Spain \\
4 th & Centers for Disease Control and Prevention & $20(2.1)$ & USA \\
5 th & University of Washington, Seattle & $19(2.0)$ & USA \\
6th & Sun Yat-Sen University & $16(1.7)$ & China \\
7 th & Mahidol University & $15(1.6)$ & Thailand \\
8 th & Universitat de ValEncia & $14(1.5)$ & Spain \\
8 th & National Institute for Occupational Safety and Health & $14(1.5)$ & USA \\
8th & The University of North Carolina at Greensboro & $14(1.5)$ & USA \\
8th & University of California, Berkeley & $14(1.5)$ & USA \\
8th & Universidad de Antioquia & $14(1.5)$ & Colombia \\
\hline SCR Stan
\end{tabular}

SCR Standard competition ranking;

aEqual institutions have the same ranking number, and then a gap is left in the ranking numbers

and Thailand were also among top ten active countries in producing research about health of migrant workers. This was unsurprising given that more than 100 million of international migrants came from Asia [3, 76].

Despite that the Arab region with approximately 11\% of the global migrant workforce had limited and even negligible contribution to literature on health of migrant workers. However, there is frequent worldwide media coverage around the South Asian construction workers building the football stadiums for the 2022 football world cup in Qatar.

The contribution of source countries to literature on migrant workers was low due to the that most of the source countries are poor or undergoing internal civil war or regional conflicts, which limits research productivity from such countries. Effective international health planning that covers migrant workers requires a certain extent of international research collaboration among different countries. Such collaboration was absent which affects collaborative efforts of screening migrant workers for potential contagious diseases that might spread by travelers. Furthermore, collaboration between sending and destination countries is required to set plans to face mental health problems for migrants and families they leave behind. Furthermore, both sending and destination countries need to collaborate to increase awareness of migrant workers about their legal and human rights at working places. Of paramount importance is the efforts directed to increase awareness about potential labor trafficking and exploitation into sex industry or dangerous labor. Finally, sending countries need to collaborate with destination countries to attract back skilled migrant workers to ensure sustainable development in sending countries.

The current study, up to the author's best knowledge, is the first bibliometric analysis of literature on the health of migrant workers. However, the current study has a few limitations. Bibliometric analysis only picks up published literature in academic journals. There are some reports in grey literature, which may be informative for the field, but were missed in this analysis. In the current study, the research strategy was designed to retrieve the maximum number of documents with minimum false positive and negative results. However, the presence of false positive and negative results is always a possibility. The use of Scopus might have created some bias towards destination countries because journals indexed in Scopus are mainly in English and produced by developed countries. Finally, data obtained might have some percentage of errors due to Scopus updating process. Therefore, a margin of error needs to be considered when interpreting top active authors, institutions, and countries. The overlap due to intra-country collaboration needs to be considered since more than one active author might share similar research output. All these limitations are typical of any bibliometric analysis and are not unique to the current study [26, 41, 77-80].

\section{Conclusion}

The current study showed that research on migrant workers' health need to be strengthened and encouraged given that the volume and growth rate were relatively inadequate. Attention to research gaps such as the focus on NCD and maternal and reproductive health is also needed. International research collaboration and research networks that include countries of origin and receiving countries were deficient. Building such collaboration and networks require recruitment of large numbers of scholars from different parts of the world to the subject of migration health in general and migrant workers' health in particular. 


\section{Abbreviation}

NCD: Non-communicable diseases

\section{Acknowledgements}

The authors would like to thank An-Najah National University for giving us the opportunity to access most recent information sources.

\section{Funding}

None

\section{Availability of data and materials}

All data presented in this manuscript are available on Scopus database using the search query listed in the methodology section.

\section{Authors' contributions}

This was a single-authored publications. WS initiated the idea, did the writing and analysis and submitted the manuscript. The author read and approved the final maunscript.

\section{Ethics approval and consent to participate}

Not applicable. IRB at An-Najah National University, Palestine requires no approval for bibliometric studies.

\section{Consent for publication}

Not applicable

\section{Competing interests}

The authors declare that they have no competing interests.

\section{Publisher's Note}

Springer Nature remains neutral with regard to jurisdictional claims in published maps and institutional affiliations.

\section{Received: 26 July 2018 Accepted: 5 October 2018} Published online: 08 November 2018

\section{References}

1. Abbas M, Aloudat T, Bartolomei J, Carballo M, Durieux-Paillard S, Gabus L, Jablonka A, Jackson Y, Kaojaroen K, Koch D, Martinez E, Mendelson M, Petrova-Benedict R, Tsiodras S, Christie D, Saam M, Hargreaves S, Pittet D. Migrant and refugee populations: a public health and policy perspective on a continuing global crisis. Antimicrob Resist Infect Control. 2018;7:113. https://doi.org/10.1186/s13756-018-0403-4

2. International Organization for Migration (IOM); Key Migration Terms.https:// www.iom.int/key-migration-terms. Accessed 15 Feb 2018.

3. International Organization for Migration (IOM); World Migration Report 2018. https://www.iom.int/wmr/world-migration-report-2018. Accessed 15 Feb 2018.

4. United Nations (UN); Transforming Our World: The 2030 Agenda for Sustainable Development. http://www.un.org/ga/search/view_doc. asp?symbol=A/RES/70/1\&Lang=E. Accessed 15 Feb 2018

5. United Nations (UN); International Migration Report 2017. http://www.un.org/ en/development/desa/population/migration/publications/migrationreport/ docs/MigrationReport2017_Highlights.pdf. Accessed 15 Feb 2018.

6. Intenational Labour Organization (ILO): Ilo Global Estimates on Migrant Workers. 2015

7. Gapen MT, Chami MR, Montiel MP, Barajas MA, Fullenkamp C: Do Workers' remittances promote economic growth?: International Monetary Fund; 2009.

8. Azam M. The role of migrant workers remittances in fostering economic growth: the four Asian developing countries' experiences. Int J Soc Econ. 2015;42(8):690-705.

9. Newland K. Migration as a factor in development and poverty reduction: the impact of rich countries' immigration policies on the prospects of the poor. In: Impact of Rich Countries' Policies on Poor Countries. Edn: Routledge; 2017. p. 187-213.

10. Moyce SC, Schenker M. Migrant workers and their occupational health and safety. Annu Rev Public Health. 2018;39:351-65.

11. Wickramage K, De Silva M, Peiris S. Patterns of abuse amongst Sri Lankan women returning home after working as domestic maids in the Middle East: an exploratory study of medico-legal referrals. J Forensic Legal Med. 2017:45:1-6.
12. Simkhada P, van Teijlingen E, Gurung M, Wasti SP. A survey of health problems of Nepalese female migrants workers in the middle-east and Malaysia. BMC Int Health Hum Rights. 2018;18(1):4.

13. Ochoa SC, Sampalis J. Risk perception and vulnerability to Stis and Hiv/Aids among immigrant Latin-American women in Canada. Cult Health Sex. 2014; 16(4):412-25.

14. Zhou YR, Majumdar B, Vattikonda N. Culture, but more than culture: an exploratory study of the Hiv vulnerability of Indian immigrants in Canada. Cult Health Sex. 2016;18(9):1067-80.

15. Gea-Sanchez M, Gastaldo D, Molina-Luque F, Otero-Garcia L. Access and utilisation of social and health services as a social determinant of health: the case of undocumented Latin American immigrant women working in Lleida (Catalonia, Spain). Health Soc Care Community. 2017:25(2):424-34.

16. Balaam MC, Akerjordet K, Lyberg A, Kaiser B, Schoening E, Fredriksen AM, Ensel A, Gouni O, Severinsson E. A qualitative review of migrant Women's perceptions of their needs and experiences related to pregnancy and childbirth. J Adv Nurs. 2013:69(9):1919-30.

17. Horyniak D, Melo JS, Farrell RM, Ojeda VD, Strathdee SA. Epidemiology of substance use among forced migrants: a global systematic review. PLoS One. 2016;11(7):e0159134.

18. McTavish FJ. Devastating consequences of sex trafficking on Women's health. Linacre Q. 2017;84(4):367-79.

19. Ottisova L, Hemmings S, Howard LM, Zimmerman C, Oram S. Prevalence and risk of violence and the mental, physical and sexual health problems associated with human trafficking: an updated systematic review. Epidemiol Psychiatr Sci. 2016;25(4):317-41.

20. Pocock NS, Kiss L, Oram S, Zimmerman C. Labour trafficking among men and boys in the greater Mekong subregion: exploitation, violence, occupational health risks and injuries. PLoS One. 2016;11(12):e0168500.

21. Abu-habib $L$. The use and abuse of female domestic workers from Sri Lanka in Lebanon. Gend Dev. 1998;6(1):52-6.

22. Sonmez S, Apostolopoulos Y, Tran D, Rentrope S. Human rights and health disparities for migrant Workers in the Uae. Health Hum Rights. 2011;13(2):E17-35.

23. Sweileh WM, Wickramage K, Pottie K, Hui C, Roberts B, Sawalha AF, Zyoud $\mathrm{SH}$. Bibliometric analysis of global migration Health Research in peerreviewed literature (2000-2016). BMC Public Health. 2018;18(1):777.

24. Tulloch O, Machingura F, Melamed C; Health, Migration and the 2030 Agenda for Sustainable Development. https://www.odi.org/sites/odi.org.uk/ files/resource-documents/10759.pdf. Accessed 15 Feb 2018.

25. Sweileh WM, Al-Jabi SW, AbuTaha AS, Zyoud SH, Anayah FMA, Sawalha AF. Bibliometric analysis of worldwide scientific literature in Mobile - health: 2006-2016. BMC Med Inform Decis Mak. 2017;17(1):72.

26. Sweileh WM. Bibliometric analysis of medicine - related publications on refugees, asylum-seekers, and internally displaced people: 2000 - 2015. BMC Int Health Hum Rights. 2017;17(1):7.

27. Sweileh WM, AbuTaha AS, Sawalha AF, Al-Khalil S, Al-Jabi SW, Zyoud SH. Bibliometric analysis of worldwide publications on multi-, extensively, and totally drug - resistant tuberculosis (2006-2015). Multidiscip Respir Med. 2016;11:45.

28. Sweileh WM, Al-Jabi SW, Sawalha AF, AbuTaha AS, Zyoud SH. Bibliometric analysis of worldwide publications on antimalarial drug resistance (20062015). Malar Res Treat. 2017:2017:6429410

29. Sweileh WM, Al-Jabi SW, Sawalha AF, AbuTaha AS, Zyoud SH. Bibliometric analysis of publications on campylobacter: (2000-2015). J Health Popul Nutr. 2016;35(1):39

30. Sweileh WM, Al-Jabi SW, Zyoud SH, Sawalha AF. Bibliometric analysis of literature in pharmacy education: 2000-2016. Int J Pharm Pract. 2018.

31. Sweileh WM, Al-Jabi SW, Zyoud SH, Sawalha AF, Abu-Taha AS. Global research output in antimicrobial resistance among Uropathogens: a bibliometric analysis (2002-2016). J Glob Antimicrob Resist. 2018;13:104-14.

32. Sweileh WM, Sawalha AF, Al-Jabi S, Zyoud SH. Bibliometric analysis of literature on antifungal Triazole resistance: 1980 - 2015. Germs. 2017;7(1):19-27.

33. Zyoud SH, Waring WS, Al-Jabi SW, Sweileh WM. Global cocaine intoxication research trends during 1975-2015: a bibliometric analysis of web of Science Publications. Subst Abuse Treat Prev Policy. 2017:12(1):6.

34. Arcury TA, Grzywacz JG, Sidebottom J, Wiggins MF. Overview of immigrant worker occupational health and safety for the agriculture, forestry, and fishing (Agff) sector in the southeastern United States. Am J Ind Med. 2013;56(8):911-24.

35. Lim YM, Song S, Song WO. Prevalence and determinants of overweight and obesity in children and adolescents from migrant and seasonal farmworker families in the United States-a systematic review and qualitative assessment. Nutrients. 2017;9(3):188. 
36. Low WY, Tong WT, Binns C. Migrant Workers in Asia Pacific and Their Rights to health. Asia Pac J Public Health. 2015;27(6):584-7.

37. Rodriguez G, Trejo G, Schiemann E, Quandt SA, Daniel SS, Sandberg JC, Arcury TA. Latina Workers in North Carolina: work organization, domestic responsibilities, health, and family life. J Immigr Minor Health. 2016;18(3):687-96.

38. Sadarangani SP, Lim PL, Vasoo S. Infectious diseases and migrant worker health in Singapore: a receiving Country's perspective. J Travel Med. 2017;24(4).

39. Salami B, Meherali S, Salami A. The health of temporary foreign Workers in Canada: a scoping review. Can J Public Health. 2016;106(8):e546-54.

40. Simkhada PP, Regmi PR, van Teijlingen E, Aryal N. Identifying the gaps in Nepalese migrant Workers' health and well-being: a review of the literature. J Travel Med. 2017;24(4).

41. Sweileh WM. Global research output in the health of international Arab migrants (1988-2017). BMC Public Health. 2018;18(1):755.

42. Van Eck NJ, Waltman L. Text mining and visualization using Vosviewer. In: arXiv preprint arXiv:11092058; 2011.

43. Opthof T, Wilde AA. The Hirsch-index: a simple, new tool for the assessment of scientific output of individual scientists: the case of Dutch professors in clinical cardiology. Neth Heart J. 2009;17(4):145-54.

44. SClmago; Scimago Journal and Country Rank (Sjr). https://www.scimagojr.com/. Accessed 15 Feb 2018.

45. Magaña CG, Hovey JD. Psychosocial stressors associated with Mexican migrant farmworkers in the Midwest United States. J Immigr Health. 2003;5(2):75-86.

46. Hovey JD, Magaña CG. Psychosocial predictors of anxiety among immigrant Mexican migrant farmworkers: implications for prevention and treatment. Cult Divers Ethn Minor Psychol. 2002;8(3):274-89.

47. Grzywacz JG, Quandt SA, Early J, Tapia J, Graham CN, Arcury TA. Leaving family for work: ambivalence and mental health among Mexican migrant farmworker men. J Immigr Minor Health. 2006:8(1):85-97.

48. Alderete E, Vega WA, Kolody B, Aguilar-Gaxiola S. Lifetime Prevelance of and risk factors for psychiatric disorders among Mexican migrant farmworkers in California. Am J Public Health. 2000;90(4):608-14.

49. Pransky G, Moshenberg D, Benjamin K, Portillo S, Thackrey JL, Hill-Fotouhi C. Occupational risks and injuries in non-agricultural immigrant Latino workers. Am J Ind Med. 2002;42(2):117-23.

50. McCurdy SA, Samuels SJ, Carroll DJ, Beaumont JJ, Morrin LA. Agricultural injury in California migrant Hispanic farm workers. Am J Ind Med. 2003;44(3):225-35.

51. McCauley LA, Lasarev MR, Higgins G, Rothlein J, Muniz J, Ebbert C, Phillips J. Work characteristics and pesticide exposures among migrant agricultural families: a community-based research approach. Environ Health Perspect. 2001;109(5):533-8.

52. Arcury TA, Quandt SA, Cravey AJ, Elmore RC. Farmworker reports of pesticide safety and sanitation in the work environment. Am J Ind Med. 2001;39(5):487-98.

53. Ahonen EQ, Benavides FG, Benach J. Immigrant populations, work and health - a systematic literature review. Scand J Work Environ Health. 2007; 33(2):96-104.

54. Parrado EA, Flippen CA, McQuiston C. Use of commercial sex workers among Hispanic migrants in North Carolina: implications for the spread of Hiv. Perspect Sex Reprod Health. 2004;36(4):150-6.

55. Mou J, Cheng J, Zhang D, Jiang H, Lin L, Griffiths SM. Health care utilisation amongst Shenzhen migrant workers: does being insured make a difference? BMC Health Serv Res. 2009:9:214.

56. Win A. The migrant worker: visible, yet invisible. BMJ Case Reports. 2015;2015.

57. Fernández C, Ortega C. Labor market assimilation of immigrants in Spain: employment at the expense of bad job-matches? Span Econ Rev. 2008; 10(2):83-107.

58. Takala J, Hamalainen P, Saarela KL, Yun LY, Manickam K, Jin TW, Heng P, Tjong C, Kheng LG, Lim S, et al. Global estimates of the burden of injury and illness at work in 2012. J Occup Environ Hyg. 2014;11(5):326-37.

59. Sterud T, Tynes T, Mehlum IS, Veiersted KB, Bergbom B, Airila A, Johansson B, Brendler-Lindqvist M, Hviid K, Flyvholm MA. A systematic review of working conditions and occupational health among immigrants in Europe and Canada. BMC Public Health. 2018;18(1):770. https://doi.org/10.1186/s12889-018-5703-3.

60. Marmot M, Friel S, Bell R, Houweling TA, Taylor S. Commission on social determinants of $\mathrm{H}$ : closing the gap in a generation: health equity through action on the social determinants of health. Lancet. 2008;372(9650):1661-9.

61. Manoyos V, Tangmunkongvorakul A, Srithanaviboonchai K, Yangyuenkul S, Grimes RM. Sexual risk-behaviors for Hiv infections among young crossborder migrant workers living in urban Chiang Mai, Thailand. J Health Res. 2016:30(5):347-53.
62. Zhussupov B, McNutt LA, Gilbert L, Terlikbayeva A, El-Bassel N. Migrant Workers in Kazakhstan: gender differences in Hiv knowledge and sexual risk behaviors. AIDS Behav. 2015;19(7):1298-304.

63. Norris AH, Loewenberg Weisband Y, Wiles M, Ickovics JR. Prevalence of sexually transmitted infections among Tanzanian migrants: a cross-sectional study. Int J STD AIDS. 2017;28(10):991-1000.

64. Marx G, Stinson K, Deatrich M, Albanese B. Notes from the field: hantavirus pulmonary syndrome in a migrant farm worker — Colorado, 2016. MMWR Morb Mortal Wkly Rep. 2017;66(02):62-3.

65. Rock B, Catherin N, Mathew T, Navshin S, Kurian H, Sherrin S, Goud BR, Shanbhag D. Alcohol use and mental health among migrant workers. Indian J Public Health Res Dev. 2016;7(4):169.

66. Siriwardhana C, Wickramage K, Siribaddana S, Vidanapathirana P, Jayasekara B, Weerawarna S, Pannala G, Adikari A, Jayaweera K, Pieris S, et al. Common mental disorders among adult members of 'Left-Behind' International migrant worker families in Sri Lanka. BMC Public Health. 2015;15(1):299.

67. Nadim W, AlOtaibi A, Al-Mohaimeed A, Ewid M, Sarhandi M, Saquib J, Alhumdi K, Alharbi A, Taskin A, Migdad M, et al. Depression among migrant Workers in Al-Qassim, Saudi Arabia. J Affect Disord. 2016;206:103-8.

68. Lam KK, Johnston JM. Depression and health-seeking behaviour among migrant Workers in Shenzhen. Int J Soc Psychiatry. 2015;61(4):350-7.

69. Adsul BB, Laad PS, Howal PV, Chaturvedi RM. Health problems among migrant construction workers: a unique public-private partnership project Indian J Occup Environ Med. 2011;15(1):29-32.

70. Davis A, Meyerson BE, Aghaulor B, Brown K, Watson A, Muessig KE, Yang L, Tucker JD. Barriers to health service access among female migrant Ugandan sex Workers in Guangzhou, China. Int J Equity Health. 2016;15(1):170.

71. Dias S, Gama A, Pingarilho M, Simões D, Mendão L. Health services use and Hiv prevalence among migrant and National Female sex Workers in Portugal: are we providing the services needed? AIDS Behav. 2017;21(8):2316-21.

72. Laohasiriwong W, Khongthanachayopit S. Accessibility to health services among migrant Workers in the Northeast of Thailand. F1000Research. 2017;6:972.

73. Betancourt GS, Colarossi L, Perez A. Factors associated with sexual and reproductive health care by Mexican immigrant women in new York City: a mixed method study. J Immigr Minor Health. 2013;15(2):326-33.

74. Otero-Garcia L, Goicolea I, Gea-Sanchez M, Sanz-Barbero B. Access to and use of sexual and reproductive health services provided by midwives among rural immigrant women in Spain: Midwives' perspectives. Glob Health Action. 2013;6:22645.

75. International Labour Organization (ILO); China [https://www.iom.int/ countries/china]; 24 Sept 2018.

76. United Nations. International migration report 2015; 2017. p. 2015

77. Sweileh WM. Bibliometric analysis of literature on toxic epidermal necrolysis and Stevens-Johnson syndrome: 1940 - 2015. Orphanet J Rare Dis. 2017; 12(1):14.

78. Sweileh WM. Bibliometric analysis of peer-reviewed literature in transgender health (1900 - 2017). BMC Int Health Hum Rights. 2018;18(1):16.

79. Sweileh WM, Al-Jabi SW, Zyoud SH, Sawalha AF. Outdoor air pollution and respiratory health: a bibliometric analysis of publications in peer-reviewed journals (1900 - 2017). Multidiscip Respir Med. 2018;13:15.

80. Zyoud SH, Sweileh WM, Awang R, Al-Jabi SW. Global trends in research related to social Media in Psychology: mapping and bibliometric analysis. Int J Ment Health Syst. 2018;12:4

Ready to submit your research? Choose BMC and benefit from:

- fast, convenient online submission

- thorough peer review by experienced researchers in your field

- rapid publication on acceptance

- support for research data, including large and complex data types

- gold Open Access which fosters wider collaboration and increased citations

- maximum visibility for your research: over $100 \mathrm{M}$ website views per year

At $\mathrm{BMC}$, research is always in progress.

Learn more biomedcentral.com/submission 